\title{
Fiscal decentralization and economic growth: A dilemma between theory and empiricism
}

\author{
Azar Hasanli \\ Azerbaijan State University of Economics, Azerbaijan
}

\section{Introduction}

The issue of abandoning fiscal decision-making authority by central government in favor of local and regional-level governance bodies has become a global process extending to most countries across the world. Over last decades, fiscal decentralization has been assessed as a mechanism for constraining the expansionary tendencies of political powers. According to distinguished scholars Buchanan and Musgrave (1999), who have contributed to decentralization theory, although, historically, the distribution of government authority between central and local governments has been an ineffective system; decentralization is an important process in terms of ensuring controls over the central government and increasing people's opportunities for participation in local decision-making authority (Svyaneich, 2003). Albeit public discussions regarding which of these-centralized or decentralized state government proceed, in both political and economic terms, most advanced countries choose to practice the second one. Due to either the failures in economic planning by central governments or rapidly changing international economic and political conjecture, the emergence of decentralization is seemed as a contemporary trend among developing and transition economies.

Traditionally, the theoretical and empirical analysis of fiscal decentralization has given little attention to the objective of economic growth. During the period following World War II, and in particular the 1960s and 1970s, many nations -both developed and developing- embarked upon a strong centralization of government policy and functions.

The basic economic case for fiscal decentralization is the enhancement of economic efficiency: the provision of local outputs that are differentiated according to local tastes and circumstances results in higher levels of social welfare than centrally determined and more uniform levels of outputs across all jurisdictions. Fiscal decentralization is commonly thought to restrict the growth of government spending. Just as tax competition in an era of globalization is believed to place 
constraints on the revenue-raising capacity of governments, inter-jurisdictional competition within decentralized countries is believed to hamper government's ability to tax.

On the other side, the effect of decentralization on economic growth is another controversial issue that has been widely discussed in both theoretical and empirical terms. Neither the theoretical arguments for the positive impact of fiscal decentralization on economic growth due to the presence of economic efficiency gains, nor the scarce empirical evidence for it are conclusive. The empirical approaches can be also differed in several aspects: the selection of different economies, the time period chosen, the economies' level of development and the estimation methodology. There are few empirical studies that analyze the relationship between fiscal decentralization and economic growth, and unfortunately the evidence on this topic is inconclusive.

\section{Theoretical background}

While looking through a vast range of economical literature, diverse approaches has been confronted toward fiscal decentralization and its influence on improving economic efficiency, managing public financial policy and social policy. Summarizing, these opinions, fiscal decentralization can be assessed as the devolution by the central government to local governments (states, regions, municipalities) of specific functions with the administrative authority and fiscal revenue to perform those functions (Kee, 2003). It can also be explained as the division of public expenditure and revenue between levels of government, and the discretion given to regional and local government to determine their budgets by levying taxes and fees and allocating resources (Davey, 2003). The European Charter of Local Self-Government also defines the framework for fiscal decentralization. According to Article 9 of the carter local authorities shall be entitled, within national economic policy, to adequate financial resources of their own, of which they may dispose freely within framework of their powers.

The theoretical base of fiscal decentralization dates from $17^{\text {th }}$ and $18^{\text {th }}$ century philosophers, including Rousseau, Mill, de Tocqueville, Montesquieu and Madison because of distrusting central governments' ability to preserve the liberties of free men and maintain its ruling function (Faguet, 1997).The modern case for decentralized government was articulated by Wolman Bennet (1990) who appreciated necessity for decentralization using two parameters: (1) efficiency values- "maximization" of social welfare taking into account inability of the public sector to contain the same price signals as the private sector, to regulate supply and 
demand; (2) governance values including responsiveness and accountability, diversity, and political participation.

Two interrelated issues should be mentioned while investigating fiscal decentralization. The first is the division of spending responsibilities and revenue sources between levels of government (national, regional, local). The second is the amount of discretion given to regional and local governments to determine their expenditures and revenues. Davey suggests that dimension of power and responsibility between central and local governments substantially depends on these factors:

$>$ what range of public services they finance;

$>$ whether their revenues are commensurate with these responsibilities;

$>$ how much real choice they have in allocating their budget to individual services;

$>$ whether they can determine the rates of their taxes and charges

Fiscal decentralization also referred to as fiscal federalism can be broadly defined as the study of the structure and functioning of multi-tiered governments. According to Oates's (2005) dividing, researches relating to this issue can be sorted into two strands:

The first-generation theory which including contributions of Samuelson (1954), who defined the nature of public goods, Arrow (1970), who conceptualized the roles of the private and public sectors, and Musgrave (1959), who proposed the functions of the government (income distribution, market failure correction, and macroeconomic stabilization). Based on these investigations, it would be best for the central government to take a lead in macroeconomic stabilization policy, income redistribution, and provision of national public goods. Local governments would be best positioned to provide local public goods because of their superior knowledge of local preferences. On the other hand, central government should monitor and balance the provision of local public goods aiming to prevent negative spillovers which can affect other local governments. The issue of taxation in multilayered government is one of the main problems known as the "tax assignment problem" which a number of researches were addressed to. This generation suggests that local governments ought to focus on property taxes and user fees. It also claims that because of highly mobility of taxes bases which would lead to relocation of people to the areas with relatively low tax rates, execution of other sort of taxes by local authorities can create distortions in the location and levels of economic activity. 
The second generation encompasses a range of contributions to the theory of federalism focus on information problems, moral hazard, and free riding among the various levels of governments. Some scholars like Weingast (1995) and McKinnon (1997) especially accentuate the reliance on local government's own sources of revenues for the finance of decentralized budgets. They also distinguish between hard versus soft budget constraints where soft budget constraints are ignored by the local governments on the belief that a bailout by the central government is possible. This became known as the problem of "raiding the fiscal commons." Rodden (2003) expanded these ideas by suggesting that it is not decentralization that matters per se but what form it takes. Summarizing his opinion, decentralization process with local governments relying on their own resources should be more efficient than a decentralization based on transfers which could also lead to perverse forms of decentralization.

The fiscal federalism theory has focused on the perspective of efficiency and the distributive consequences of a fiscal decentralization. Although the traditional argument for fiscal decentralization is that it may provide greater economic efficiency in the allocation of resources in the public sector (Oates, 1972), the relationship in direct and indirect form between efficiency and economic growth has been analyzed to a very limited extent. The theory maintains in case of having various preferences for public goods between jurisdictions, an attempt to provide unique provision of them by central government cannot achieve the same level of efficiency as a decentralized provision. It also offers that supplying the best combination of public services and local tax rate is possible only when there are incentives and mobility for individuals to move to the jurisdiction. Therefore, decentralizing revenue rising and spending decisions are appreciated as a significant method to improve the public sector efficiency, reduce budget deficit and promote economic growth by a number of scholars including Bird (1993) and Gramlich (1993).

The experience indicate us that meeting all of the competing needs of local authorities is gradually impeding central governments to sustain their other constitutional activity which in turn make them attempt to build local capacity by delegating responsibilities downward to their regional governments with the purpose to assist them on national economic development strategies. Moreover, regional and local political leaders demand more autonomy and want the taxation powers that go along with their expenditure responsibility. At this point, it ought to mention that most authors assume that the subnational- local or regional governments are in a better position than the central government knowing the potential factors of growth, that is, their territory needs in infrastructures, education or innovation and research. Thus, if they have expenditure autonomy, they can 
design a strategy of growth more adapted to the reality of their territory. Financing expenditure autonomy of these local authorities can be in several forms like (1) intergovernmental transfers- $(a)$ shares of national taxes distributed either by formula or by origin; $(b)$ grants/subventions which are either targeted to support specific expenditures or untargeted and used at the discretion of local government (often known as block grants) or (2) capital expenditures basically financed from i)grants from the State Budget or national funds; ii)operating surplus; iii)sale of assets; iv)credit (loans or bonds).

Nevertheless, if there are economies of scale in the production of the public good decentralized provision may be more inefficient than when it is centralized. (Rothenberg 1970) Some researchers claim that existing spillover effects, corruption and externalities between authorities indeed lead to economically inefficiency losses in massive amounts. The rationale for decentralization of revenues is not the same as expenditures and fiscal decentralization may limit the ability of the principal (the central government) to influence policy at the local level. Elsewhere, Brennan and Buchanan (1980) argued that taking into consideration sub-national governments' incentives to maximize their budget fiscal decentralization may contribute to containing the size of their budgets and thus restraining the overall size of the public sector in case of these authorities compete in objectives other than revenue maximization, such as keeping tax rates stable or even lowering them, and the efficient production of public goods under certain revenue constraints. Another argument against decentralization is relating to economic efficiency which suggests that it requires roughly even regional fiscal capacities - a condition not existing in developing countries. Based on these arguments, decentralization may even increase fiscal inequities in developing countries. In addition, localities might engage in destructive competition to attract industry. Tanzi (1996) summarizes this critique by raising a number of situations or conditions, especially in developing countries, where fiscal decentralization may lead to less than an optimal result:

* Taxpayers may have insufficient information or no political power to pressure local policymakers to make resource-efficient decisions.

- Local politicians may be more corrupt than national politicians or at least find themselves in more corrupting situations.

* The quality of national bureaucracies is likely to be better than local bureaucracies.

* Technological chance and increased mobility may reduce the number of services that are truly "local" in nature.

* Local governments often lack good public expenditure management systems to assist them in their tax and budget choices. 
Fiscal decentralization may exacerbate a central government's ability to deal with structural fiscal imbalances.

Finally, there may be some inefficiency due to corruption in the assignment of some services. These losses can generate lower growth, because they can be greater than the possible gains of producer efficiency that could be produced in a context of fiscal decentralization.

\section{Relation between decentralization and economic growth}

There is no clear cut dealing with the effect of decentralization of economic growth. Not only the theoretical arguments but also empirical studies analyzing the relationship between fiscal decentralization and economic growth are not conclusive. Aiming to quantify the impact of decentralization on the achievement of higher levels of economic growth, a variety of studies were conducted which took into account multiple definitions of decentralization as well national-regional level estimations. While most of the theories on fiscal decentralization argue for a positive association between both variables, the empirical evidence is inconclusive, with an increasing number of studies showing a negative correlation between decentralization and economic performance. The majority of the empirical studies highlighting a positive association between both factors concern developed countries. Many studies indicate that the success of decentralization processes is a consequence of not only the design of the decentralization model but, perhaps more importantly, of country characteristics, and especially of the existence of strong effective institutions at all government tiers. (Dabla-Norris, 2006) Empirical results vary among state-regional level and the consideration of developed and nondeveloped countries. All these studies use different definitions of decentralization measures and economic control variables in the specification of the growth equation. Most of these studies start up from a neoclassical growth model, while some have used partial considerations derived from endogenous growth models. The neoclassical approach identifies which would be the factors to consider under a Cobb-Douglas production function or the best ones for estimation in a $\beta$ convergence framework. However because of some scholars' criticisms of the robustness of the estimations of the chosen neoclassical model and also the suggestion that the mean average would not be representative for the economies considered as a whole on the other, create doubts relating to the appropriateness of habitual estimations to the real relation between decentralization and economic growth. 
Studies originally centered around the arguments in favor of fiscal decentralization suggest that it leads higher efficiency, better public service, greater transparency and, eventually, economic growth. It is considered that because of local governments' better positioning than central ones to deliver public services as a result of proximity and informational advantage, decentralization increase efficiency. (Klugman, 1994) This approach is especially significant factor for the low-developed and emerging countries where lack of markets opportunities and functionality make people rely on actions by governments. Moreover, taking into consideration population mobility and competition among local governments in the delivering of public services, the idea that local governments are better equipped to provide a more adequate service to the local population than central governments comes again to the fore. Decentralization may thus improve not only the potential for achieving Pareto efficiency, but also for achieving greater economic equality across territories. Subnational governments are often bound by balanced budget requirements, which fuel procyclicality, as local expenditure and revenue move together. Making transfers to local governments more contingent on the cycle would help mitigate the adverse impact of fiscal decentralization on macroeconomic stabilization. The legal fiscal framework could include such a provision, to be triggered when the severity (IMF, 2015). Thiessen (2003) considers that decentralized expenditures may lead to greater "consumer efficiency". In addition, because of difference in the amount of demands in each territory, resources can be saved by diversifying governments' outputs in accordance with local demands (Martínez- Vazquez and McNab, 2003). Another aspect related with fiscal decentralization concerns the incentive to innovate in the production and supply of public goods in order to reduce production costs and, hence, increase public sector productivity. This is an important argument that favors decentralization (Feld et al., 2004) and economic growth. It is due to the fact that the experimentation and innovation in the provision of local or regional public goods and services may generate greater producer efficiency. Hence, subnational governments can produce more output (or better quality output) than the central government, with the same level of expenditures. Eventually, the higher quantity or quality of the locally provided public services could generate a higher income increase, and this is a measure of growth. More recently, some works dealing with connections between decentralization and growth are centered on the possibility of preserving and promotion of the development of markets. It is believed that appropriately structured intergovernmental fiscal arrangements may create sufficient incentives for subnational governments to foster markets. Moreover, if the central government is a source of policy inefficiency, decentralization may improve resource allocation, foster market development, and, in turn, promote economic growth. 
Based on analysis of long years and experience from different countries, key advantages of fiscal decentralization provision can be listed as below:

Fiscal decentralization is one of the core conditions in ensuring the application of the principle of subsidiarity in empirical studies- holding tasks and responsibilities are transferred to the lowest possible level of government which is the closest to the people;

Fiscal decentralization boosts transparency in the public money spending -unlike central and other governmental units, it is easier and more durable to share public scrutiny mechanisms for fiscal resources used by local governments;

Fiscal decentralization increases allocative efficiency in terms of managing public means - an efficiency in which limited resources are allocated for those types of goods and services that are more desirable in t society and also in high demand. (Zimmermann, 2003)

Some studies even consider it harmful, especially in the case of developing and transition economies. This skepticism is fuelled by problems often associated with decentralization, such as increasing deficits, lower quality of government decisions, corruption, increased influence of interest groups and greater interregional inequalities, which may result in lower overall economic growth. It is often the case that carefree subnational governments have built up unsustainable deficits and called upon central governments to assume their liabilities and in some cases provide special bailout transfers. Recent studies have tended to find that increasing subnational deficits lead to higher central government expenditures and debt along with higher inflation rates. This is especially a concern in the case of the fast implementation of decentralization in parts of Central and Eastern Europe. It is also difficult for governments to implement macroeconomic stabilization in decentralized frameworks, because of the considerable economic 'leakage' associated with local expenditures According to Thiessen (2003), the variance of incomes between households and regions which produce inequities under fiscal decentralization, the lack of sub-national governments' incentives to act countercyclically, the quality of governments and of local democracy, low per capita income levels, a country's small size, the scarcity of good local taxes, the low degree of urbanization and the lack of goods and services that qualify as public are the ones affect the quality of fiscal decentralization.

Existing of vulnerability of democracy and political accountability in developing and transition economies, the delivery of resources and public services constitute the greater risk group of corruption and opportunistic behavior at lower levels of government. In this case, fiscal decentralization carries higher possibility of reinforcing regional inequalities to the detriment of overall economic growth. 
Decentralization can make it less likely that certain regions benefit from sharing of best practices and economies of scale and as in many less developed regions the level of training of staff in local government is lower than elsewhere, even managing basic tasks such as accounting and record-keeping can become problematic (Odero, 2004).

Based on these empirical facts, fiscal decentralization is assessed fundamentally suitable for developed countries with relatively high levels of per capita income which prevent taxpayers from the problems that associated with lower income countries by some researchers. Experiences of various countries show us that in spite of the fact that naturally decentralization has been shaped in large measure by political, historical, and ethnic realities, its effectiveness and successful implementation is influenced by the comprehensive institutional design and capacities at all tiers of government.

On the other side, while analyzing studies pointing to fiscal decentralization's positive effect on growth, measured from either the revenue or expenditure point of view. However, there are also some works as Davoodi and Zou (1998) who analyzed a panel data set of forty-six developed and developing countries using a specification based on the Barro model and reported a negative relationship for both the whole panel data set and the panel data set of developing countries; or Woller and Phillips (1998) for twenty-three less developed countries, by Zhang and Zou (2001) for the Chinese provinces, and by Xie, Zou and Davoodi (1999) for the US. (Espasa et al., 2007)

\section{Measurement and empirical controversies}

The main reasons contributing such appearing differences drastically among empirical researches can be explained with these relevant factors: (1) the economic development level and (2) the fiscal decentralization threshold that has been exceeded in each central regional decentralization process. Additionally, choosing the indicator with the purpose to use in measuring the fiscal decentralization is also controversial issue which is become serious while conducting empirical analysis on the consequences of fiscal decentralization or finding a more appropriate measure of the prevailing degree of decentralization in a chosen country. Summarizing the most quantitative measures used in theoretical researches to define degree of decentralization, these ones can be highlighted:

Decentralization of expenditure responsibilities- reflects the level of autonomy powers and responsibilities of sub-national governments; 
Tax decentralization - entails the scope of autonomy responsibilities of local governments in shaping local revenues;

Level of independence of local fiscal system - the level of government participation, efficiency, flexibility and transparency of transfer system in shaping intergovernmental transfer system, the level of ratio of transfers to subnational and provincial budgets to transfers from revenue resources;

Drawing right decentralization - reflects the level of opportunity to make independent decisions by local governments. (Agayev, 2013)

Generalized coefficient called "Fiscal Decentralization Index" is used broadly to prevent from inadequateness stemming from various methodologies of assessment. Conceptually, FDI can be divided into two broad categories: (i) the fiscal autonomy of subnational governments- the ratio "local revenue to total local expenditures" without taking into consideration central government transfers; (ii) the fiscal importance of subnational governments- the ratio of local government expenditures to total government expenditures minus central government transfers to local government. A Decentralization Index (FDI) range from zero to 100 in which $0<\mathrm{FDI}<50$ describes "relative fiscal centralization" while $50<\mathrm{FDI}<100$ illustrates as "relative fiscal decentralization".

On the other hand, most studies assume a budgetary perspective and use measures constructed by taking the ratio of sub-federal revenues and/or spending to total government revenue and/or spending. Especially in cross-country studies, such measures are usually constructed on the basis of the IMF's Government Finance Statistics (GFS) dataset. One well recognized drawback of the GFS measures is that they provide an inaccurate picture of the "true" level of decentralization. As Rodden (2004) notes, GFS uses the revenue obtained by sub-federal governments at face value while taking the expenditures undertaken and ignoring these resources' mandating by central government regulations. Therefore, there is a great probability that GFS measures might incorrectly offer a high degree of decentralization, in spite of the fact that autonomy of sub-federal governments over fiscal matters might actually be negligible. Moreover, because of massive transfers from consolidated tax revenues to local authorities, the GFS can indicate high level of revenue decentralization, albeit local governments' power on deciding tax rates and bases is substantially restricted. That is, a large value of the GFS measures for revenue decentralization might not necessarily imply a large amount of de fact autonomy.

There are several attempts with the purposes to compensate deficiencies of the GFS decentralization measure. Thornton (2007) used a measure which originally provided by OECD and involved differentiating sub-federal tax revenue according 
to the level of autonomy sub-federal governments have over the associated rates and bases, and then calculating the ratios with regard to total government tax receipts. Even though the data used by Thornton provide a better approximation of the true extent of decentralization than the GFS measures there are two drawbacks. Firstly, they are only available as a cross-section dataset and, secondly, for 19 countries only. The results obtained in this measure imply no robust relationship between fiscal decentralization and economic growth and might be distorted due to unobserved heterogeneity and/or small-sample biases. Rauscher develops an endogenous growth model with Leviathan governments in which fiscal competition due to decentralization leads to a reduced frequency of political innovation and lower economic growth (Feld and Baskaran, 2009).

In the light of the given the measurement problems, it is not surprising that the researches on the impact of fiscal decentralization on economic growth by diverse authors end up with controversial results. In the Table 1, various cross-countries researches illustrate that difference in development levels of studied countries and using methodologies in these studies contribute controversial results.

Table 1. Empirical studies on the influence of fiscal decentralization or federalism on economic growth in cross-country studies ${ }^{1}$

\begin{tabular}{|c|c|c|c|c|}
\hline Study & Countries & Period & Method & Main results \\
\hline $\begin{array}{l}\text { Davoodi and } \\
\text { Zou (1998) }\end{array}$ & $\begin{array}{l}46 \text { Developing } \\
\text { and Developed } \\
\text { Countries }\end{array}$ & $\begin{array}{l}1970-1989 \\
\text { five and ten } \\
\text { year averages }\end{array}$ & $\begin{array}{l}\text { Fixed } \\
\text { Effects } \\
\text { Model, Time } \\
\text { Dummies, } \\
\text { Unbalanced } \\
\text { Panel }\end{array}$ & $\begin{array}{l}10 \% \text { higher } \\
\text { decentralization of } \\
\text { spending reduces growth } \\
\text { of real GDP per capita in } \\
\text { developing countries by } \\
0.7-0.8 \% \text {-points ( } 10 \% \\
\text { significance level) }\end{array}$ \\
\hline $\begin{array}{l}\text { Woller and } \\
\text { Philipps } \\
\text { (1998) }\end{array}$ & $\begin{array}{l}23 \text { Developing } \\
\text { Countries }\end{array}$ & $\begin{array}{l}\text { 1974-1991 } \\
\text { three and five } \\
\text { year averages } \\
\text { and annual } \\
\text { data }\end{array}$ & $\begin{array}{l}\text { Fixed } \\
\text { Effects } \\
\text { Model, OLS }\end{array}$ & $\begin{array}{l}\text { No robust significant } \\
\text { effect of the decen- } \\
\text { tralization of spending or } \\
\text { revenue on growth of } \\
\text { real GDP per capita }\end{array}$ \\
\hline Yilmaz (2000) & $\begin{array}{l}17 \text { Unitary } \\
\text { States, }\end{array}$ & $\begin{array}{l}\text { 1971-1990 } \\
\text { annual data }\end{array}$ & $\begin{array}{l}\text { Fixed } \\
\text { Effects }\end{array}$ & $\begin{array}{l}\text { Decentralization of } \\
\text { expenditures at the local }\end{array}$ \\
\hline
\end{tabular}

\footnotetext{
${ }^{1}$ This table is originally taken from the paper called "Fiscal Federalism, Decentralization and Economic Growth: A Meta-Analysis" by Lars P. Feld, Thushyanthan Baskaran, Jan Schnellenbach based on their own compilation.
} 


\begin{tabular}{|c|c|c|c|c|}
\hline & $\begin{array}{l}13 \text { Federal } \\
\text { Countries, } \\
\text { Newly } \\
\text { Industrialized } \\
\text { Countries and } \\
\text { Developed } \\
\text { Countries }\end{array}$ & & $\begin{array}{l}\text { Models, } \\
\text { Time } \\
\text { Dummies, } \\
\text { GLS }\end{array}$ & $\begin{array}{l}\text { level increases growth of } \\
\text { real GDP per capita in } \\
\text { unitary states more than } \\
\text { in federal countries. } \\
\text { Decentralization at the } \\
\text { regional level is not } \\
\text { significant }\end{array}$ \\
\hline $\begin{array}{l}\text { Ebel and } \\
\text { Yilmaz (2002) }\end{array}$ & $\begin{array}{l}6 \text { Transition } \\
\text { Countries }\end{array}$ & 1997-1999 & $\begin{array}{l}\text { Bivariate } \\
\text { OLS }\end{array}$ & $\begin{array}{l}\text { Decentralization is in } \\
\text { general positively related } \\
\text { to economic growth }\end{array}$ \\
\hline $\begin{array}{l}\text { Eller } \\
(2004)\end{array}$ & $\begin{array}{l}22 \text { OECD } \\
\text { Countries }\end{array}$ & $\begin{array}{l}\text { 1972-1996, } \\
\text { annual and } \\
\text { four year } \\
\text { averages }\end{array}$ & $\begin{array}{l}\text { Fixed } \\
\text { Effects, } \\
\text { Time Dum- } \\
\text { mies }\end{array}$ & $\begin{array}{l}\text { Decentralization is } \\
\text { positively related to } \\
\text { economic growth }\end{array}$ \\
\hline $\begin{array}{l}\text { Enikolopov } \\
\text { and } \\
\text { Zhuravskaya } \\
(2003)\end{array}$ & $\begin{array}{l}21 \text { Developed } \\
\text { and } 70 \\
\text { Developing and } \\
\text { Transition } \\
\text { Countries }\end{array}$ & $\begin{array}{l}\text { Cross-section } \\
\text { of the } \\
\text { averages } \\
1975-2000\end{array}$ & OLS, 2SLS & $\begin{array}{l}10 \% \text { higher } \\
\text { decentralization of } \\
\text { revenue reduces growth } \\
\text { of real GDP per capita in } \\
\text { developing countries by } \\
0.14 \% \text {-points ( } 5 \% \\
\text { significance level) }\end{array}$ \\
\hline $\begin{array}{l}\text { Thiessen } \\
\text { (2003) }\end{array}$ & $\begin{array}{l}21 \text { Developed } \\
\text { Countries }\end{array}$ & $\begin{array}{l}\text { Cross-section } \\
\text { of the } \\
\text { averages of } \\
1973-1998\end{array}$ & OLS & $\begin{array}{l}\text { Decentralization of } \\
\text { spending by } 10 \% \\
\text { increases growth of real } \\
\text { GDP per capita by } \\
0.15 \% \text {-points ( } 5 \% \\
\text { significance level), } \\
\text { quadratic term is } \\
\text { significantly negative }\end{array}$ \\
\hline $\begin{array}{l}\text { Thiessen } \\
(2003 a\end{array}$ & $\begin{array}{l}26 \text { Developed } \\
\text { Coun-tries }\end{array}$ & $\begin{array}{l}\text { Panel data } \\
1981-1995\end{array}$ & GLS & $\begin{array}{l}\text { Decentralization of } \\
\text { spending by } 10 \% \\
\text { increases growth of real } \\
\text { GDP per capita by } \\
0.12 \% \text {-points ( } 5 \% \\
\text { significance level). }\end{array}$ \\
\hline Iimi (2005) & $\begin{array}{l}51 \text { Developing } \\
\text { and Developed } \\
\text { Countries }\end{array}$ & $\begin{array}{l}\text { Cross-section } \\
\text { of the average } \\
\text { of } 1997 \text { to } \\
2001\end{array}$ & OLS, IV & $\begin{array}{l}10 \% \text { higher } \\
\text { decentralization of } \\
\text { spending increases } \\
\text { growth of real GDP per }\end{array}$ \\
\hline
\end{tabular}




\begin{tabular}{|c|c|c|c|c|}
\hline & & & & $\begin{array}{l}\text { capita by } 0.6 \% \text {-points } \\
\text { (1\% significance level) }\end{array}$ \\
\hline $\begin{array}{l}\text { Feld, } \\
\text { Baskaran and } \\
\text { Dede (2004) }\end{array}$ & $\begin{array}{l}19 \text { OECD } \\
\text { countries }\end{array}$ & $\begin{array}{l}\text { Panel data } \\
1973-1998\end{array}$ & $\begin{array}{l}\text { Fixed } \\
\text { Effects, } \\
\text { Time Dum- } \\
\text { mies }\end{array}$ & $\begin{array}{l}\text { No robust effect of } \\
\text { spending or revenue } \\
\text { decentralization, but a } \\
\text { significantly negative } \\
\text { effect of stronger } \\
\text { participation in revenue } \\
\text { sharing arrangements }\end{array}$ \\
\hline $\begin{array}{l}\text { Bodman and } \\
\text { Ford (2006) }\end{array}$ & $\begin{array}{l}18 \text { OECD } \\
\text { Countries }\end{array}$ & $\begin{array}{l}\text { Cross-section } \\
\text { of } 1996 \text { and } \\
\text { Panel data } \\
1981-1998\end{array}$ & OLS & $\begin{array}{l}\text { No significant effect of } \\
\text { revenue or spending } \\
\text { decentralization on } \\
\text { economic growth }\end{array}$ \\
\hline
\end{tabular}

The main reason for empirical controversies can be considered choosing an appropriate econometric framework to indicate relationship between decentralization and economic growth. Another problem is dealing with using the plain coefficients is that different studies apply different measures of decentralization and economic growth. The estimated coefficients are not dimensionless and therefore not directly comparable across studies without some standardization according to the precision of the study. Empirical studies do also not provide strong support for an impact of federalism, decentralization or fiscal competition on economic growth. Overall, the empirical evidence is rather inconclusive whether there is an effect at all and they also suffer from the fact that often the autonomy of sub-federal jurisdictions is not properly measured.

\section{Conclusion}

According to the theory of fiscal federalism, fiscal competition leads to efficient allocative outcomes which might eventually promote higher rates of economic growth. As accentuated above, some researchers give specific attention to a positive correlation between increasing efficiency in the state sector through fiscal decentralization and reducing disproportions between regions. On the other hand, it is sometimes considered that sustainable economic growth can be provided only by central government, while expansion of the public sector at the subnational level can boost irresponsible debt policy. Experiences indicate us that although economic growth is achieved when all public services and powers are delivered by central government, the quality of service provision is low and the role of 
institutions in civil society development are weakened. Therefore, it is often argued that decentralization is important and it is impossible to secure effective governance without redistributing main authority responsibility and financial resources among local government tiers.

With respect to the theoretical studies, possible influence channels of fiscal decentralization on economic growth can be as below:

Tiebout channel- an advantage of decentralized provision and financing of public goods, namely tailoring them to heterogeneous preferences of individuals, shows up in economic growth as resulting different savings rates might affect the transition to a steady state

$>\quad$ Structural Change channel - decentralization allows designing regional economic policies to the necessities of a regional economy, and thus increases growth in case of accompanying by sub-federal experimentation,

$>\quad$ Political Innovation channel - political innovation serves as another growth enhancing mechanism. But it is noteworthy to mention that a high degree of political instead of fiscal autonomy of sub-federal units seems to impede economic growth, as indicated by the consistently negative sign of the federation dummy.

$>$ Market-Preservation channel -decentralization, in fact, contributes to solve political economy problems

Fiscal decentralization is a multifaceted process and the nature of relationship between growth and subnational taxation or subnational expenditures is very complicated. Within the fiscal sphere, all the fiscal decentralization indicators using in both theoretical and empirical studies are intertwined and it means that if one of these elements is poorly designed or miscalculated, the real relation between growth and decentralization is become irrelevant. The design of each pillar of the intergovernmental system must be very well linked to broader decentralization reform goals and intergovernmental fiscal policy objectives. It is rather the efficiency (or inefficiency) properties of fiscal competition, fiscal equalization systems, or intergovernmental fiscal relations in a polity in general that determine the relation between fiscal federalism and economic performance. (RodríguezPose, Krøijer, 2009)

Overall and most importantly, based on the empirical studies it becomes obvious that a relationship between decentralization and growth is rather to be expected in developed, industrialized countries lending support to the suspicion that fiscal decentralization is having much different effects in less developed than in developed countries. In addition, single country studies tend to indicate a positive effect of decentralization on growth which may be the result of their possibility to 
consider the specific differences within a country more strongly. Especially various econometric models used in empirical researches can give drastically diverse results based on the structure of the economy of country. Finally, while it remains undecided how a switch from expenditure centralization measures to tax autonomy indicators affects the results in favor of fiscal decentralization or not, attempts in this issues should be designed taking into consideration features of national economic system of each country and empirical studies ought to be implemented based on much more appropriate econometric models for targeting countries.

\section{References and notes:}

Agayev, R. (2013), "Fiscal decentralization in Azerbaijan: assessing the current situation”, Baku

Arrow, K. (1970), "The Organization of Economic Activity: Issues Pertinent to the Choice of Market versus Non-Market Allocation", The Analysis and Evaluation of Public Expenditures: The PBB-System, vol. 1

Bennet, R.J. (1990), “Decentralization: Local Governments and Markets”, London

Bird, R. (1993), "Threading the Fiscal Labyrinth: Some Issues in Fiscal Decentralization”, National Tax Journal, vol. 46, pp. 207-227

Brennan, G. \& Buchanan, J. (1980), "The Power to Tax: Analytical Foundations of a Fiscal Constitution", New York

Buchanan, J. \& Musgrave, R.A. (1999), "Public Finance and Public Choice: Two Contrasting Visions of the State”, Cambridge, MIT Press, 272 pp.

Carrion-i-Silvestre, J.L., Espasa, M., Mora, T. (2007), "Fiscal Decentralization and economic growth in Spain”, Public Finance Review, vol. 36(2), pp. 194-218

Dabla-Norris, E (2006), "The challenge of fiscal decentralization in transition countries", Comparative Economic Studies, vol. 48, pp. 100-131

Faguet J.P. (1997), "Decentralization and Local Government Performance", Technical Consultation on Decentralization, FAO, ROME

Feld, L.P., Zimmermann, H., \& Döring, T. (2004), "Federalism, Decentralization, and Economic Growth", Marburg

Gramlich, E.M. (1993), “A policy-maker's guide to fiscal decentralization”, National Tax Journal, vol.46 (2), pp. 229-235 
International Monetary Fund (2015), "Fiscal Monitor: Now Is the Time Fiscal Policies for Sustainable Growth", Washington

Kee, J.E. (2003), "Fiscal Decentralization: theory as reform”, The George Washington University

Klugman, J. (1994), "Decentralization: A survey of literature from a human development perspective", New York, UNDP Human Development Report Office

Lars P. Feld, Baskaran, T. (2009), "Fiscal Decentralization and Economic Growth in OECD Countries: Is there a Relationship?", CESifo Working Paper No. 2721

Lars P. Feld, Baskaran, T., Schnellenbach, J. (2014), "Fiscal Federalism, Decentralization and Economic Growth: A Meta-Analysis", Heidelberg

Martinez-Vazquez, J. \&McNab, R.M. (2003), "Fiscal decentralization and economic growth", World development, vol. 31 (9), pp. 1597-1616

McKinnon, Ronald I., (1997), "Market-Preserving Fiscal Federalism in the American Monetary Union," in: Macroeconomic Dimensions of Public Finance: Essays in honour of Vito Tanzi

Musgrave, R.A. (1959), “The Theory of Public Finance”, New York: McGraw Hill.

Matondang,S.A.(2017)," Multicultural Identity of Singapore as Ex-British Settlement and New Asian Global City", International Journal of Humanities and Social Development Research, Vol 1(1).Baku.pp.49-60

Oates, W.E. (1972), "Fiscal Federalism”, New York, National Tax Journal, 46(3), pp. 237- 243

Oates, W.E. (2005), "Toward A Second-Generation Theory of Fiscal Federalism", International Tax and Public Finance, vol. 12, pp. 349-73

Odero, K.K.(2004), "PRSPs in decentralized contexts: Comparative lessons on local planning and fiscal dimensions", Washington, The World Bank Publications

Rodden, J. (2003), "Reviving Leviathan: Fiscal Federalism and the Growth of Government", Massachusetts, International Organization Journal, vol. 57(4), pp. 695-729

Rodden, J. (2004), “Comparative Federalism and Decentralization: On Meaning and Measurement", Comparative Politics, vol. 36, pp. 481-500

Rothenberg, J. (1970), "Inthe Analysis of Public Output: Local decentralization and the theory of optimal government", New York, National Bureau of Economic Research

Rodríguez-Pose, A. \&Krøijer, A. (2009), "Fiscal Decentralization and Economic Growth in Central and Eastern Europe", London, LEQS Paper No. 12/2

Samuelson, P. (1954), "The Pure Theory of Public Expenditure", Review of Economics and Statistics, vol. 36(4), pp. 387-389.

Samandarov S.(2016),"Assessments regarding the issue of development of the steel industry in the economic literature in the 20-ies century Azerbaijan", Baku, Khazar Journal of Humanities and Social Sciences, Vol 19(1),pp.50-56

Svyanevich P. (2003), "Principles of fiscal decentralization”, Guide book for transit economy countries, Budapest

Tanzi, V. (1996), "Fiscal Federalism and Decentralization: A Review of Some Efficiency and Macroeconomic Aspects", IBRD// The World Bank

Thiessen, U. (2003), "Fiscal decentralization and economic growth in high income OECD Countries", German Institute for Economic Research, Berlin

Thornton, J. (2007), "Fiscal decentralization and economic growth reconsidered", Journal of Urban Economics, vol. 61(1), pp. 64-70 
Weingast, B.R. (1995), "The economic role of political institutions: market preserving federalism and economic development", Journal of Law, Economics and Organizations, 15 (1), pp. 1-31

Zimmermann, H., (2003) “Municipal finances”, Moscow, Delo i Servis, pp. 68-73 


\title{
Summary
}

\section{Fiscal decentralization and economic growth: A dilemma between theory and empiricism}

\author{
Azar Hasanli \\ Azerbaijan State University of Economics
}

\begin{abstract}
Abandoning fiscal decision-making, redistributing and dispersing authorities provided by central government in favor of local and regional-level governance bodies is one of the widely discussed issues across the world based on the theory of "fiscal decentralization". Incumbent theoretical and empiric researches regarding to achieving economic growth in the light of global economic fragilities indicate that managerial allocation of public funds among central and local authorities casts significant attention in terms of optimizing economic efficiency. In the article, it is tried to introduce brief theoretical background and measurement techniques to depict empiric relationship between fiscal decentralization and economic growth. In addition to investigating empiric facts, an effort to reveal the impact of fiscal decentralization on acquiring economic growth is made. Based on the investigations conducted in the framework of the article, it becomes obvious that empirical approaches toward the issue can be differed in several aspects: the selection of different economies, the time period chosen, the economies' level of development and the estimation methodology. However, there are few empirical studies that analyze the relationship between fiscal decentralization and economic growth, and unfortunately the evidence on this topic is inconclusive.
\end{abstract}

Keywords: Fiscal decentralization, Economic growth, Efficiency, Provision of funds, Governance. 